\title{
Moving East: how the transnational tobacco industry gained entry to the emerging markets of the former Soviet Union- part Il: an overview of priorities and tactics used to establish a manufacturing presence
}

\author{
A B Gilmore, M McKee
}

Tobacco Control 2004;13:151-160. doi: 10.1136/tc.2003.005207

See end of article for authors' affiliations

.....................

Correspondence to: Dr Anna B Gilmore, European Centre on Health of Societies in Transition, London School of Hygiene and Tropical Medicine, Keppel Street, London WCIE 7HT, UK; anna. gilmore@|shtm.ac.uk

Received 11 July 2003 Accepted 26 December 2003

\begin{abstract}
Objectives: To explore how British American Tobacco (BAT), having established cigarette imports, responded to the opportunities for investment in cigarette manufacturing in the former Soviet Union (FSU). Design: Analysis of documents held at the BAT archive in Guildford, UK.

Results: Considerable priority was attached to investing in the FSU. This led BAT to undertake a major organisational change and to intense competition to acquire assets. BAT used flawed economic arguments to persuade cash starved governments that its investment would reap economic rewards. It offered excise advice that disadvantaged governments while benefiting BAT, confused issues over pricing, and avoided competitive tendering. BAT targeted agriculture ministries, using its expertise in leaf production to differentiate itself from other potential investors. It subverted the principles of corporate social responsibility to promote itself as a business partner. BAT's task was made easier by the naivety of post-Soviet governments and by the international financial organisations' support for rapid economic reform. The latter permitted tobacco transnationals to penetrate markets before effective competitive tendering processes had been established, giving them the opportunity to minimise prices and establish monopolies. Conclusions: Many of the arguments employed when penetrating post-Soviet markets were highly misleading but governments lacked expertise to realise this. There is a need to build tobacco control capacity in transition economies, within and outside government, to ensure that governments are better informed of the true economic and health impacts of tobacco. Rapid transition from socialist to market economies without establishing regulatory institutional structures may be dangerous when investing companies use business practices that fall short of international standards.
\end{abstract}

$\mathrm{T}$ his is the second of two papers that explore the tactics that British American Tobacco (BAT) used to enter the new markets of the former Soviet Union (FSU). In the first paper we established that, based on initial exploratory visits to the region ${ }^{1-3}$ and advice from western firms already active in the area, BAT had outlined a cautious, stepwise approach to market entry that could be divided into two main phases-first to establish imports, and second a manufacturing presence. ${ }^{2}$ This paper focuses on the second of these phases.

Despite BAT's initial concerns about the risks and costs of establishing a joint venture or green field operation, ${ }^{14}$ it soon recognised that it could not build a significant market presence without establishing domestic manufacturing facilities. ${ }^{4}$ This paper explores how BAT responded to the new opportunities for investment in cigarette manufacturing in the FSU, how it prioritised these opportunities and, above all, the tactics it used to establish a manufacturing presence. It aims to give a brief overview of these tactics, while future papers will explore the individual tactics in more detail.

Before exploring these issues, some background to the unprecedented market reforms underway at that time is needed. When the Berlin Wall fell in 1989, one of the world's most profound economic transitions began, gaining momentum with the collapse of the Soviet Union in 1991. Key challenges in the transformation from a command economy include the creation of markets and privatisation of state owned enterprises. Fierce debates centred on the speed of reform $^{5}$ and led to the emergence of two schools of thought. The "shock therapy" approach of rapid and extensive privatisation assumed that private ownership would itself be sufficient to ensure efficiency and that competitive policies and institutional safeguards could safely follow at a later date. ${ }^{6}$ In the more "gradualist" approach that had been successful in China, the creation of a competitive environment and necessary institutional infrastructure and regulation were seen as necessary precursors to privatisation. The reformers advising Russia and the global financial institutions, particularly the US Treasury and the International Monetary Fund (IMF) advocated shock therapy ${ }^{5}$ and in less than a decade hundreds of thousands of small scale firms and approximately 60000 medium and large scale firms were privatised across the former communist bloc. ${ }^{7}$ This was nearly 10 times the number of privatisations seen in the rest of the world in the previous 10 years. $^{7}$ Although some successes have been seen in central and eastern Europe, even some of the strongest advocates of this policy now argue that the consequences for the FSU were largely disastrous. ${ }^{5}$ As a result, life under capitalism has for many been far worse than under Communism. ${ }^{58}$

The tobacco industry was just one of the many privatised. In Russia, for example, the state monopoly was abolished in 1992 and state tobacco firms were transformed into independent joint stock companies that were then privatised,

\footnotetext{
Abbreviations: BAT, British American Tobacco; BATUKE, BAT United Kingdom and Export; EBRD, European Bank for Reconstruction and Development; IMF, International Monetary Fund; NBD, New Business Development; FSU, former Soviet Union; TTCs, transnational tobacco companies
} 
enabling the transnational tobacco companies (TTCs) to acquire their assets. " A similar model applied in other republics, although subject to differences in the overall pace and extent market reforms, ${ }^{10}$ leading to major differences in tobacco industry structure.

Between 1992 and the start of 2001 the major TTCs made significant investments in Russia, Ukraine, Latvia, Lithuania, Estonia, Kazakhstan, Kyrgyzstan, and Uzbekistan. ${ }^{11}$ Because of political unrest, privatisation and investment in the Caucasian republics was relatively slow-Armenia has received minor tobacco investments since 1997, and Azerbaijan since 1999 following the abandonment of initial investments. ${ }^{11}$ In 1998 the Georgian industry was privatised and although the TTCs did not invest directly, in 2001, BAT established a licensing operation. This leaves only four countries without direct TTC involvement (bar their large import presence)-Belarus, Moldova, Tajikistan and Turkmenistan (which does not have a manufacturing capacity). These countries are, for various reasons, the most difficult for foreign companies to operate in.

\section{METHODS}

The BAT archive in Guildford UK was searched between July 2001 and February 2002. The methods have been described in detail elsewhere. ${ }^{2}$ Essentially it was searched manually onsite using 171 search terms in a broad and iterative approach. This retrieved 1803 files (many of which were duplicates), from which over 600 documents were studied in detail. Documents were indexed in a database which enabled the sorting of documents by date and topic to construct a historical and thematic narrative. Supplementary data were obtained from tobacco industry journals, newspapers, routine data, and other published reports.

\section{RESULTS}

Restructuring BAT group operations to maximise new business opportunities

Investment in new markets, particularly those in the Eastern bloc countries, was such a priority within BAT that it led to the creation of a new, dedicated unit and a major company restructuring. At a series of high level meetings in the early 1990s Patrick Sheehy (chairman, BAT Industries), Ulrich Herter (managing director tobacco, BAT Industries), and others $^{12-14}$ agreed to establish a New Business Development unit (NBD) to maximise BAT's opportunities in emerging new markets. The unit was described as "a central team to co-ordinate the identification and assessment of investment opportunities, to prepare proposals and to be responsible for the negotiations leading up to investments in eastern Europe and the USSR" ${ }^{12}$ Although the unit's final remit extended beyond this region, particularly to the Far East, ${ }^{15}$ opportunities for investment in the FSU were the immediate priority. ${ }^{12}$

The NBD unit was actively supported by Sheehy and Herter, ${ }^{16}$ and given high status within the company, transferring to BAT's London headquarters in February 1992 because Sheehy "perceived that greater impetus would be created in grasping new business opportunities if the function reported centrally". ${ }^{17}$ Yet the unit alone was insufficient to deal with the many opportunities available at that time $^{18} 19$ and BAT, concerned that its decentralised structure was a disadvantage in developing new business opportunities compared with its competitor Philip Morris, ${ }^{17} 20$ undertook further changes. ${ }^{17}$ The most significant was a major company restructuring, in January 1993, entitled "Project Rubicon". Two of BAT's operating groups, BAT Co. and BATUKE (BAT United Kingdom and Export), combined their management capacity and restructured along regional lines, creating four regional business units that divided the world market among them. It was felt that closer coordination between domestic and export marketing operations would enhance the ability of BATCo "to exploit the growing opportunities for its brands in world markets". ${ }^{21}$

\section{Prioritising investments within the region}

Relative to Philip Morris, BAT had little experience in the FSU. ${ }^{22}$ This is reflected in recurrent misspellings of country and politician's names, ${ }^{23}{ }^{2414}$ and attempts to obtain advice from other large multinationals. ${ }^{24}{ }^{25}$ Inexperience, combined with the rapid political changes at the time, resulted in chaotic initial attempts to prioritise countries for investment. The earliest ranking listed East Germany, Hungary, Czechoslovakia, Yugoslavia, Poland, Bulgaria, and Romania, followed by the then USSR. ${ }^{26}$ By September 1991, the USSR had collapsed and priorities changed. Hungary was identified as the "best short-term prospect for investment" and Russia, Ukraine, and Moldova as showing "the most promising potential" ${ }^{12}$ The relative priority given to countries continued to vary ${ }^{13}$ until 1992 when a clearer system was established and priority markets were identified as those which were:

$$
\begin{aligned}
& \text { "-of sufficient size; } \\
& \text {-potentially profitable; } \\
& \text {-likely to be open for investment within two to three years; } \\
& \text {-not already committed to a competitor". }
\end{aligned}
$$

This led to a more systematic list of 39 first and second priority countries, 23 of which were in the former communist bloc, with all 15 FSU countries listed as either first or second priority. ${ }^{15} 27$ In order of appearance on BAT's "first priority" list were Ukraine, Russia, Poland, and Macedonia (by this time BAT had acquired the Pécs factory in Hungary). ${ }^{15}$ Thereafter the order changed slightly, although usually for obvious reasons. For example, as trouble flared in the Balkans, Macedonia and Serbia disappeared from the list, ${ }^{27}$ while Uzbekistan was prioritised ${ }^{18}$ as a result of a review of central Asia. ${ }^{28}$

Prioritisation was based largely on the existing and potential cigarette market size. ${ }^{15} 28$ Russia stood out by virtue of its sizable population (149 million) and the former Communist markets differed from others prioritised by BAT by their relatively high rates of consumption. ${ }^{27}$ This was especially so for Poland and Hungary ${ }^{29}$ which then had among the highest rates of tobacco consumption in the world. In central Asia the gap between existing cigarette production and estimates of potential demand may also have been a key factor-the countries prioritised had the widest gap as well as the largest potential demand..$^{28}$ Beyond these main criteria, political and economic circumstances and geographical location were taken into account although they were rarely adverse enough to exclude a potential investment. $^{28}{ }^{30}$ For example, Schroders advised BAT against investment in Kyrgyzstan due in part to political instability, ${ }^{28}$ yet BAT still pursued this possibility. ${ }^{31}$ Similarly BAT (along with at least one other TTC) spent from early 1993 to the end of 1995 attempting to invest in the Grodno Tobacco Factory in Belarus, ${ }^{32}{ }^{33}$ when other investors realised that market liberalisation was most unlikely under President Lukashenka, ${ }^{34}{ }^{35}$ who even BAT's advisers had described as an "unbalanced farmer". ${ }^{36}$

\section{Issues of competition}

Although BAT had established a staged approach for entering the former Soviet markets that allowed for a gradual increase in the level of investment and risk required, ${ }^{2}$ ultimately, once the communist system collapsed, they had to act far faster than anticipated. 
The competition to acquire assets was intense. In Uzbekistan alone 14 letters of intent were signed for the establishment of a joint venture with the Tashkent Tobacco Factory between 1991 and mid $1993 .{ }^{37}$ Even by late 1993, as BAT was finalising a deal to acquire this factory, Uzbek government offices were being "deluged with letters from various consultants fronting for PMI [Philip Morris International], RJR [RJ Reynolds] and Rothmans". ${ }^{38}$

BAT recognised Philip Morris as their most "aggressive" competitor, ${ }^{39}$ but others were also a threat, particularly RJ Reynolds, Rothmans, ${ }^{40}$ and Reemtsma, which according to BAT aimed to be the largest company in Europe and was "expanding aggressively in eastern Europe in pursuit of this goal". ${ }^{39}$

Our analysis suggests pressure to acquire assets rapidly arose for three main reasons. Firstly, a perceived window of opportunity in which the absence of marketing restrictions and low costs of advertising could be exploited in order to establish cigarette brands in new markets. ${ }^{21}$ Secondly, competition between the TTCs and thirdly, the industry's wish to avoid competitive tendering.

Competition to acquire factories inflated prices $^{31}$ and BAT discovered that its competitors were prepared to pay considerably more, thereby exacerbating concerns about the threat of competitive tendering: ${ }^{42}$

"BAT's experience in recent months shows that Philip Morris is prepared to offer substantially higher prices in situations where BAT and Philip Morris compete to acquire a controlling interest in a monopoly cigarette supplier in the former eastern bloc ("FSU"). Specifically, BAT believes it was outbid by a factor of up to some three times in both Klaipeda in Lithuania, where Philip Morris was the successful bidder, and Almaty in Kazakhstan, where Philip Morris has made the winning offer in a competitive tender...

Over the last 3 years a number of deals have been structured involving the exchange of western skills and finance for ownership interests in FSU and Asian factories. Initially, these deals were very often achieved as the product of bilateral negotiations with local partners who where (sic) often perceived as having a very uncertain future in the absence of aid. In each case, control passed to the western company. The deals BAT struck in Hungary and Ukraine typified this approach.

As the number of deals has increased, it has become evident that western investors are prepared to place a significant value or "premium" on participation in the emerging markets. It now appears that a trend is developing towards the local factory (or its owner, the state) adopting a more demanding stance and putting the opportunity out to competitive tender.

...While BAT may have failed to outbid Philip Morris in two cases, this could merely reflect a preparedness of Philip Morris' part to overpay for what they consider "strategic" markets"

Notably, despite the intense competition between TTCs to acquire assets, this rivalry rarely resulted in open tenders and the anticipated benefits for the seller, but led instead to closed deals wherein the TTCs could gain the advantage. BAT went out of its way to avoid a competitive process, ${ }^{42}$ doing so successfully in Ukraine ${ }^{43}$ and Uzbekistan ${ }^{31}{ }^{44}$ and attempting the same in Russia ${ }^{45}$ and initially in Moldova. ${ }^{46}$ Other TTCs were playing the same game. ${ }^{47}$ In Belarus, where BAT attempted unsuccessfully to acquire the Grodno tobacco factory, it deliberately sought to confuse the Belarussians about the size of its offer, which was under half that offered by Reynolds:
"BAT may be forced to uncloak its offer which has hitherto been deliberately supported by 'smoke and mirrors'. BAT's offer actually values Grodno at $\$ 22.3$ million (less than half RJR's offer). ${ }^{\prime 48}$

The TTCs' desire to establish monopoly positions ${ }^{49}$ undoubtedly exaggerated the pressure to acquire assets rapidly. So too did the regional approach to investment in which marketing and manufacturing strategies were to be more tightly coordinated on a regional basis ${ }^{20}$ and an individual country was seen as providing a manufacturing base for a whole region. Thus BAT saw Moldova as the site from which to export to the Caucasus (Armenia, Azerbaijan, and Georgia) and Uzbekistan as BAT's centre in central Asia.. ${ }^{51}$ An approach presumably aided by the TTCs' apparent willingness to facilitate cigarette smuggling into countries where they did not have production facilities. ${ }^{2}$

In many instances the TTCs successfully established monopoly positions even in populous countries. ${ }^{11}$ BAT established a monopoly in Uzbekistan, Reemtsma in Kyrgyzstan, and Philip Morris in Lithuania along with a virtual monopoly in Kazakhstan. Traditionally, the absence of competition in monopoly markets results in the absence of advertising with potential advantages for tobacco control. Here, however, the documents suggest that even where BAT anticipated establishing a monopoly position, its marketing plans were developed on the basis of a competitive market due to the perceived threat from imports and desire to establish brands before possible advertising restrictions. ${ }^{50}$

\section{Tactics}

Having noted that "Eastern Europe cannot be seen as a monolithic, political and economic block... [but that]... [e]very market must be looked at and analysed individually and the relevant strategy for opening it up be developed and implemented individually", ${ }^{26}$ BAT devised a set of tactics to gain entry. These had been identified early as part of the NBD strategy where it was noted that:

"If BAT Industries is to be successful in entering new markets it must:

-make early contacts in the priority countries;

-be quick to respond and be flexible;

-build up the trust of the relevant governments by advising over industry structure and excise;

-make agreements with governments that are transparently fair if the they are to survive changes in regimes; -be prepared to commit to investment;

-be prepared to offer licensed manufacture of our International Brands in order to build up local awareness of the brand supported by advertising;

-offer leaf and manufacturing know-how;

-be prepared to barter if necessary, especially leaf;

-win the confidence of local manager by explaining BAT's decentralised culture, offering to upgrade facilities, explaining how improved sales and marketing expertise and the introduction of selected international brands, can benefit the company, and explaining management incentives." 18

\section{Contacts}

At one of the earliest meetings on new business development it was noted that the first priority for the NBD team would be to travel widely in the region and establish contacts at the highest level. ${ }^{12}$ It would be assisted in this task by consultants "who had good connections with the leading industry and 
political figures in the country"13 and accredited representatives who would "maintain contacts with national authorities" ${ }^{18}{ }^{18}$ BAT's use of political contacts was absolutely key and so extensive that it cannot be covered in detail here. Rather, we will focus on the way in which BAT sought to "build up the trust of the relevant governments", firstly by selling the benefits of privatisation and transnational investments in general, and secondly in promoting BAT versus its rivals.

\section{Selling the benefits of privatisation}

BAT had remarked in relation to Poland that "[t]he difficult stage is to get the business privatised"52 While most postSoviet governments were receptive to privatisation, others, most notably in BAT's context those of Belarus and Moldova, were resistant. BAT therefore set about using a number of tactics to persuade such governments of the benefits.

In this they were supported by the international financial institutions. The IMF, for example, assisted by pushing generally for privatisation in Belarus, as BAT's advisers noted:

\section{"Lukashenko [President of Belarus] initially put a stop to the privatisation process, but re-started it in March under pressure from the IMF, which was withholding credit until the Government showed more commitment to economic reform." 53}

The same was seen in Moldova when government failure to approve tobacco industry privatisation led the IMF to suspend its Extended Fund Facility disbursements in $1999 .{ }^{54} 55$ This, in turn, led to temporary suspension of the World Bank structural adjustment credit disbursements (although loans continued in other sectors) and European loans. ${ }^{545657}$

In relation to Belarus, BAT argued in documentation prepared for the Deputy Prime Minister Ling's visit to the UK, that there was an:

\section{"...urgent need for investment in Tobacco Factory Grodno to modernise and expand production facilities, to improve quality and quantity of cigarettes for supply to the Belarusian market and to replace imports coming into the country without duty being paid. The increase in production at Grodno and the replacement of imports by domestic production will result in Government revenues being increased." 58}

It also emphasised the "increasing fiscal and excise revenues to the Belarusian Government" as one of the benefits of BAT's investment. ${ }^{59}$ BAT maintained this stance despite documents suggesting the company was itself responsible for smuggling cigarettes to the region ${ }^{2}$ and continues to market its brands heavily in Belarus ${ }^{60}$ where $40 \%$ of cigarettes are smuggled or counterfeit, despite having little official market share. ${ }^{61}$ Other tactics used to facilitate privatisation of the Grodno factory included the use of government insiders to push for privatisation and help ensure the replacement of a resistant factory leader with one more receptive to BAT's approaches. ${ }^{62-66}$

BAT also wanted to invest in Moldova which, as a major leaf producer, had extensive facilities and a cigarette factory reputed to be the best in the region. ${ }^{13526768}$ A series of slides and figures perhaps produced to sell a BAT joint venture option to the Moldovans reviews three options for the tobacco industry. It suggests that the single joint venture option (as opposed to no foreign investment or dismantling of the monopoly with privatisation of individual units) would maximise foreign income and government revenue, ${ }^{69}$ but ignores the effective monopoly power that this would give BAT.

To further illustrate the potential benefits of BAT's investment to the Moldovan government, the Minister of Agriculture and others were invited by Sir Patrick Sheehy to visit Brazil to demonstrate that despite the industry being privately owned, the Brazilian government still derived substantial revenue from it. ${ }^{57}$

\section{Economic arguments and excise advise}

Economic arguments were also used in the less resistant countries. Notes on Patrick Sheehy's visit to Uzbekistan and meeting with President Karimov outline how Sheehy emphasised that increased quality and exports of tobacco leaf plus import substitution could increase government revenues:

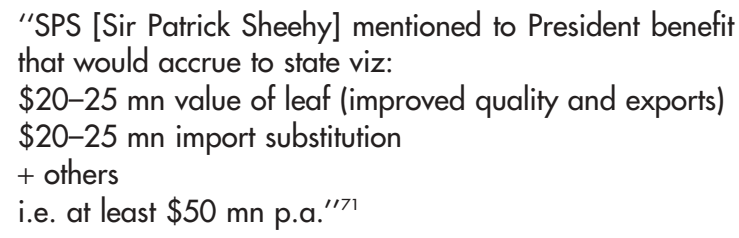

A hand written note next to this memo also indicates that Sheehy was keen to stress the macro-economic benefit of investment. Such claims were repeated publicly ${ }^{72}$ and made elsewhere for example in Ukraine where Sheehy, again in direct contact with the President, Leonid Kravchuk, emphasised the importance of tobacco taxation revenue and suggested that, with BAT's input, leaf imports could be reduced. ${ }^{73}$

Plans to use such economic arguments had been developed at one of the early meetings that established BAT's strategy for new markets where it was decided that:

\begin{abstract}
"Mr Herter would set up a small team independent of New Business Development Department, who would offer a service to governments, indicating the revenue earning possibilities of tobacco and other products and advising on the optimum structure for excise regimes. Discussions which the Chairman had with Mr. Attali and Mr. Freeman at EBRD [the President and Vice President respectively of the European Bank of Reconstruction and Development] suggested that funds could be available to cover the cost of specific projects undertaken by the team. ${ }^{114}$
\end{abstract}

The European Bank for Reconstruction and Development (EBRD) was established in 1991 to nurture a new private sector and use investment to help build market economies in the region. Since its inception it has had a policy of not loaning for tobacco. ${ }^{74}$ BAT record that EBRD staff approached the company in October 1991 to enquire whether the bank "could help BAT to fund projects in Eastern Europe". ${ }^{75}$ This led to plans for the chairman to contact EBRD to establish whether the bank could provide assistance with financing ${ }^{13}$ and resulted in the discussions detailed above. According to EBRD however, BAT misinterpreted their approach which was aimed at the broader group of companies then subsumed within the BAT Industries portfolio (at the time BAT was divesting its retail assets and concentrating on tobacco and financial services). ${ }^{76}$ Although there can be no doubting that BAT would have seen EBRD as a valuable ally, there is no record of EBRD providing assistance or funding to BAT (personal correspondence Beverley Harrison and Chris Beauman, EBRD, 2003).

While BAT sought to promote its excise advice as a service to prospective business partners, ${ }^{71} 7778$ other documents make 
clear that the advice was proffered largely for BATs benefit. $^{79}{ }^{80} 50$ As outlined in the 1993 draft BAT Industries Strategy:

\begin{abstract}
"Priority will be given to initiating dialogues with governments on excise in order to establish appropriate excise structures compatible with the structure of our new product ranges.

Rationale: The structure of excise can greatly affect the structure and profitability of our markets. BAT has wide expertise which it can use to advise governments on how to achieve their objectives while not distorting cigarette markets and at the same time improving our competitive position. ${ }^{\prime 20}$
\end{abstract}

\section{Selling BAT}

In both the resistant and receptive countries, BAT used a number of tactics to sell itself as preferable to its competitors as a joint venture partner. A simple tactic was to arrange for key players to visit BAT's established ventures such as the Pécs factory in Hungary, its first joint venture in the region, to persuade them that "BAT are good and welcome foreign partners." ${ }^{\prime 1}$ Other tactics included the promotion of BAT's image as a responsible partner and selling BAT's strengths.

\section{The corporate image}

We saw in our previous paper that BAT thought that the promotion of its corporate image would assist in opening up new markets. ${ }^{20}$ This ploy was used in a number of ways.

In 1993, just as the competition for assets in the FSU escalated, the World Tobacco Symposium was held in Moscow and used as a venue to promote BAT's image. In his keynote speech, Ulrich Herter attempted to sell BAT's role as a tax collector along the lines described above:

"Not only do we collect excise but we also advise and set up schemes in many countries, that will deliver to their governments the revenues they need in a predictable and orderly way."

The speech then went on to promote BAT's apparent altruism:

"[F]or me the most satisfying area is sponsorship of the arts.

Our company has recently brought a young Russian musician to London to perform in a classical concert and, on a larger scale, next month we are bringing The Art of Holy Russia exhibition to London's Victoria and Albert museum." ${ }^{\prime \prime 2}$

Other superficially altruistic actions were undertaken in Moldova at the point when BAT was bidding against Reemtsma to acquire assets there. ${ }^{57}{ }^{83-85}$ Elsewhere however, as notes on a visit to St Petersburg make clear, BATs assistance (like that of Philip Morris) was predicated on direct advantages to the company:

"PM [Philip Morris] has been looking at a project involving the renovation of the Moscow City Centre (Boulevard Ring) including bus shelters, kiosks, lighting systems etc. This project is being developed by an Italian architect with connections to the Raucci family who are exclusive exporters to Russia of Marlboro (26 million per day). The project is expected to cost $\$ 20 \mathrm{~m}$ and is likely to be rewarded with 49 years advertising in the city centre. Although I believe PM could well be looking at such a project nobody would be foolish enough to expect a guarantee of anything in Russia particularly for 49 years. I suggest we explore the avenue of assisting the Moscow government with infrastructure improvements only if we can derive benefit in the short term. For example during JV negotiations. $^{1 / 86}$ [emphasis added]

Selling BAT's strengths

BAT also went out of its way to sell its perceived strengths in relation to other TTCs. The strengths identified included:

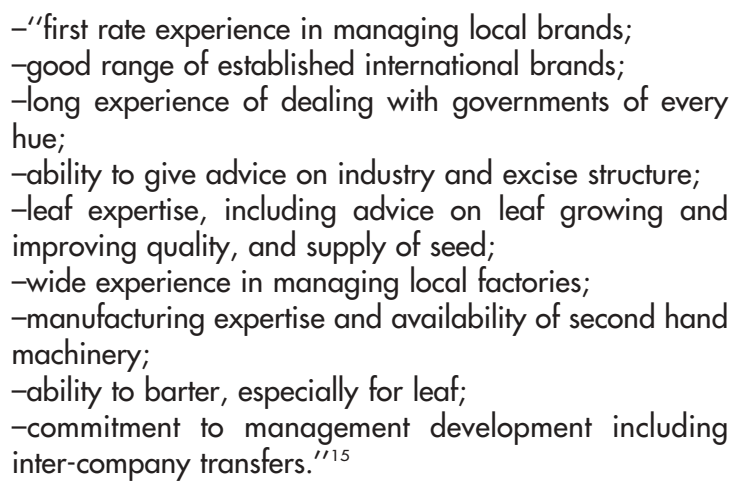

- "first rate experience in managing local brands; -good range of established international brands; -long experience of dealing with governments of every hue;

-ability to give advice on industry and excise structure;

-leaf expertise, including advice on leaf growing and improving quality, and supply of seed;

-wide experience in managing local factories; -manufacturing expertise and availability of second hand machinery;

-ability to barter, especially for leaf;

-commitment to management development including inter-company transfers. ${ }^{\prime 15}$

Offers of assistance in these areas were used in varying degrees and according to the needs of the host country in order to promote BAT as a potential partner. In most instances it was clearly to BAT's advantage to provide these services in any joint venture it established. During negotiations to establish a joint venture with the Prilucky factory in Ukraine for example ${ }^{87}$ BAT offered to supply "know-how, management skills, marketing and distribution skills, technology, access to trade marks etc." ${ }^{18}$ Similar offers were made in Belarus and Uzbekistan, ${ }^{89}{ }^{90}$ with the addition in Belarus of guarantees of employment, sponsorship of the local community, ${ }^{59}$ and legal support for an ongoing dispute. ${ }^{64}$ In some instances more devious offers were made. For example, in Uzbekistan BAT planned to contract the Tashkent factory to manufacture an extra five billion cigarettes per year using BAT owned secondary equipment in order "to lock the Uzbek authorities into an agreement to negotiate a JV [joint venture] exclusively with BAT by the simple expedient of demonstrating quickly a genuine commitment to assist the Tashkent factory". ${ }^{90}$

Two key areas of expertise: tobacco leaf and local brands

These general offers of assistance, including the excise advice outlined above, tended to also be offered by BAT's competitors. However, BAT differentiated itself from its competitors through two more unique areas of expertise as a letter from Sheehy to President Nazerbayev of Kazakhstan illustrates:

"Our proposals will certainly differ from those of our competitors in two key respects. First, unlike those competitors, we have considerable experience in developing domestic leaf crops; in Brazil alone over 220,000 tonnes of tobacco are grown by farmers under contract to BAT every year. No other company can match our record in this area. Secondly, whilst our proposals feature the development of international brands at the Alma-Ata cigarette factory, we do not believe that all smokers in 
Kazakhstan will necessarily either be able to afford, or indeed will wish to smoke, these cigarettes. A significant element of our proposal therefore features the development of existing national brands at affordable prices. ${ }^{\prime \prime 91}$

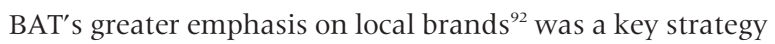
differentiating itself from the competition ${ }^{91}{ }^{93}$ and one seen as attractive in the FSU. ${ }^{92}$ It occurred for a number of reasonsBAT's lack of a truly global brand on a par with those of its competitors, its historical emphasis on local brands, ${ }^{94}$ and most importantly because of the greater profit margins gained from these brands in the early years of investment. ${ }^{14} 79$ BAT's experience from their first acquisition in the region, the Pécs factory in Hungary, had shown that "the upgrading of local brands offers the best immediate prospects for significant increases in market share and profits". ${ }^{14}$ This was particularly the case in times of economic hardship. Philip Morris, who may have learnt the hard way, having been left with a warehouse full of unsold Marlboro cigarettes in Russia, ${ }^{95}{ }^{96}$ also adopted this policy. ${ }^{97}$

BAT's favourite sales pitch, however, was its tobacco leaf expertise. As noted in the 1993 draft Tobacco Strategy: "High quality Leaf, and the provision of advice to farmers, is one of BAT's key competitive strengths, particularly when negotiating positions in new markets." ${ }^{20}$ BAT went out of its way to use this asset as a letter from RHL Taylor, a leaf expert within the BAT's NBD unit to BATs subsidiaries illustrates:

\section{"In presenting BAT to potential partner, NBD uses a range of material emphasising the company's strengths. One obvious, and very attractive, advantage we have over our competitors is our involvement in leaf which has proved to be a critical success factor in many of our negotiations. ${ }^{1 / 98-100}$}

BAT used this expertise to its advantage by emphasising the potential for import substitution, ${ }^{71}{ }^{73}$ offering assistance in leaf production and implementing leaf trials sometimes, it appears, purely as a public relations exercise. ${ }^{101}{ }^{102}$ It arranged for Ministry of Agriculture representatives to visit Brazil to witness the leaf produced under contract to BAT first hand. ${ }^{70}{ }^{103}$ BAT was also keen to stress the uniqueness of these skills in relation to other multinationals ${ }^{73}{ }^{104}$ pointing out, for example, to members of the Uzbek Presidential delegation to the UK in November 1993 "PMI's lack of leaf development expertise" and that "RJR had none of BAT's unique leaf development expertise" ${ }^{\prime \prime} .{ }^{105}$

These arguments successfully won allies in Ministries of Agriculture ${ }^{93103}$ who, keen to enhance their leaf production, ${ }^{106}$ were then used to support BAT's case. ${ }^{107}$ In Kazakhstan where BAT entered the bidding war very late, Van Waay noted that "[f]ollowing the visit by the Chairman, the Ministry of Agriculture appears to be pro-BAT and is keen for BAT assistance in tobacco production". ${ }^{103}$ Interestingly, Philip Morris's Kazakh proposal, which was ultimately successful in the competitive tender (not least, as referred to above, because Philip Morris offered three times more than BAT), also attempted to emphasise its leaf interests by naming Universal Leaf as a partner although according to BAT:

\footnotetext{
"PM's [Philip Morris] proposal shows that its authors do not take their own "agricultural programme" seriously. Universal Leaf (ULT) is identified as PM's "partner" at the beginning of the proposal... A local leaf development effort is promised, ...[but]... Thereafter, ULT is never mentioned in the proposal. On the contrary, PM intends to
}

introduce an American blended cigarette (Marlboro) under license, using "imported cut tobacco and materi$\mathrm{als}^{\prime \prime}$... Therefore PM does not even intend to cut the tobacco, much less grow it, in Kazakhstan."108

The relative ignorance of the FSU governments in relation to tobacco leaf was apparent. And it is ironic that BAT continuously referred to and offered trips to Brazil where Christian Aid have since highlighted the appalling plight of tobacco farmers under contract to BAT's subsidiary Souza Cruz. ${ }^{109}$

\section{DISCUSSION}

A number of issues become apparent from this overview of BAT's efforts to establish a manufacturing presence in the FSU. BAT's willingness to undertake major organisational change illustrates the priority it attached to investing in this region. The other TTCs also prioritised the region and this led to considerable pressure to acquire assets rapidly. Most notable, however, are the tactics BAT used to push for privatisation and secure investment. These included offering inappropriate economic advice to encourage privatisation and excise advice that disadvantaged governments while benefiting BAT, confusing issues over pricing, avoiding competitive tendering, and using other anti-competitive means such as the supply of secondary equipment in Uzbekistan to lock governments into deals. BAT promoted its "good" corporate image and its perceived strengths, most notably its tobacco leaf expertise, to sell itself as a suitable business partner. Its task was facilitated by the international financial organisations' support for privatisation and the naivety and inexperience of post-Soviet governments, ${ }^{35}{ }^{110}$ which BAT exploited. As notable as the industry's focus on the economic impacts of tobacco was the total absence of any debate about tobacco's health impacts. Although the industry is usually quick to document and counteract any opposing or "anti" activity ${ }^{111} 112$ and detailed the region's fledgling "anti-smoking movement" in one of its earliest reviews, ${ }^{113}$ through the remaining documents reviewed we found details of only one international tobacco control meeting held in Poland in November 1990 and attended by delegates from the Soviet Union. ${ }^{114}$ Thus, as far as we can tell, the governments of the newly independent states received little if any effective tobacco control advice or appropriate information on the true health and economic impacts of tobacco.

\section{BAT versus its competitors}

We saw previously how BAT missed the first set of state import orders and its competitors established licensing arrangements first. ${ }^{2}$ Here we see that BAT lacked experience in the region, was reluctant to pay market prices and was outbid at competitive tenders. Ultimately its competitors were quicker to establish a manufacturing presence as they had been import orders. RJ Reynolds was the first to invest in Russia and Ukraine, in the latter, despite BAT's belief it could be first into the market. ${ }^{80}$ Philip Morris also acquired assets in Kazakhstan before BAT had established their monopoly in neighbouring Uzbekistan. This suggests a surprising torpidity or cautiousness on BAT's behalf as, despite the risks involved in investing in the FSU, the odds were stacked in favour of the TTCs ${ }^{2}$; with high potential rates of consumption, a large gap between supply and demand, the support of the international financial organisations for privatisation, and little if any countervailing support for tobacco control, it was surely difficult for the TTCs to fail. Indeed to our knowledge, there is only one significant investment in the region from which the TTCs have withdrawn—RJ Reynold's initial investment in Azerbaijan. ${ }^{11} 115$ 


\section{Market reform}

The evidence presented in this paper lends weight to criticisms of the IMF's rapid reform policy by highlighting the ease and extent to which the TTCs exploited the lack of regulatory frameworks and absence of a competitive environment. They were able to avoid competitive tenders, hoodwink governments about prices, establish monopoly positions, avoid import duties through smuggling, and influence taxation systems. This lack of regulation also posed risks to the investing companies but BAT was largely aware of and seemingly happy to dismiss these and related problems. ${ }^{25}{ }^{116-118}$ Moreover, the literature suggests that while the international financial organisations considered the risks to international investors, they failed, at the time, to consider the detrimental impact that the behaviour of the oligarchs, corrupt government officials, and international investors have had on the reform process. ${ }^{5-7}$ In retrospect this reveals a degree of naïvety about the propensity of international investors to avoid competition and ignore established standards of business practice. ${ }^{119}$

\section{Economic arguments}

Just as the IMF had promised economic salvation with market reform, so too did the TTCs. Most prominent among BAT's tactics to encourage denationalisation and TTC investment was the promotion of flawed economic arguments that are worth reviewing in more detail. BAT's overall strategy was to stress the macroeconomic benefits of the development of an indigenous tobacco industry. ${ }^{14} 5871$ Put simply, these arguments are a mirror image of the economic "myths" the industry more frequently espouses to oppose the implementation of tobacco control policies. ${ }^{120}$ In practice, the complex economic impacts of tobacco remain a topic of some debate. But it is becoming increasingly clear that the economies of only very few countries, those with large tobacco leaf export sectors, depend to any great extent on tobacco ${ }^{121}$ and that, despite the early deaths of smokers, smoking seems to impose a net economic burden on a country. ${ }^{122}$ In the FSU, only Kyrgyzstan has traditionally relied to any great extent on tobacco leaf for export earnings, ${ }^{123}$ and although its tobacco leaf production has now recovered from a fall in the mid 1990s, tobacco leaf exports have declined and imports increased since the early 1990s. ${ }^{124} 125$

The strength and plausibility of the economic arguments BAT used stems from the grains of truth that lie within. Yet it was the industry that, directly or indirectly, usually prevented any potential economic benefits from accruing. The arguments fall into three main areas. Firstly that improved cigarette quality will help reduce illegal imports. ${ }^{58}$ Given that the TTCs use smuggling to pressure for market opening and were already smuggling cigarettes into the $\mathrm{FSU}^{2}{ }^{126}$ this argument was at best disingenuous. The second focused on the excise earning potential of tobacco, ${ }^{14}$ alleging that BAT investment would increase excise revenues. ${ }^{59}$ While excise can of course be raised from tobacco (or indeed any other goods), TTC investment would not per se increase excise revenues over those that could accrue via a state owned industry. Instead, given the TTCs greater propensity to lobby for excise reductions, the opposite may occur ${ }^{127}$ as witnessed in Ukraine. ${ }^{128} \mathrm{~A}$ drop in excise obviously helps the TTCs increase sales, undermines tobacco control, and further reduces government revenues already depleted through cigarette smuggling. ${ }^{2}$

The third economic argument was that import substitution of both tobacco leaf and cigarettes would lead to financial gains. $^{587173}$ The cigarette substitution argument is again clouded by the TTCs willingness to illegally import cigarettes when tax policies were unfavourable. ${ }^{2}$ Nevertheless, across the region the predicted import substitution of cigarettes has occurred to the extent that the considerable increase in cigarette imports seen from 1990 to 1996 has now stabilised. However, due to the TTCs' successful creation of demand, the vast increases in annual cigarette production, estimated at approximately 200 billion cigarettes across the region between 1991 and 2000, have been channelled directly into local consumption. ${ }^{129}$ Thus little if any increase in exports or trade surplus has yet to emerge. The suggestion that leaf imports could be substituted in countries such as Ukraine ${ }^{73}$ that had not traditionally been tobacco leaf producers seems farcical given the subsequent pronounced fall in leaf output and increase in imports. ${ }^{125} 128$ Indeed local experts have alleged that tobacco production collapsed as a direct result of TTC investment. ${ }^{128}$ BAT had noted privately, even in Kazakhstan, an area better suited to leaf production, that production of quality virginia leaf would be difficult. ${ }^{130}$ And it was surely clear that, whatever BAT's brand strategy, the entry of other TTCs to the region with their focus on international brands ${ }^{131}$ would lead to a requirement for virginia leaf rather than the traditional oriental leaf. BAT indicated as much in their comments on Philip Morris's proposal for Kazakhstan. ${ }^{108}$ United Nations Food and Agriculture Organization (FAO) data ${ }^{125}$ show that leaf imports have increased exponentially in the FSU, particularly in countries that have received tobacco industry investments. ${ }^{129}$ The fall in leaf production that started in the mid 1980 s has continued with only a minor recovery seen since 1996 in a few countries, both the traditional leaf producers, not all of which have received investment, and in Kazakhstan and Uzbekistan where the TTCs have invested. ${ }^{11}$ In addition, TTC investment has also led to an increase in various other imports including machinery, cigarette paper, and filters further influencing the trade balance. ${ }^{128}$

The experience in the Czech republic where Philip Morris commissioned a much derided report claiming that early deaths from tobacco could bring economic benefits shows how far along the line of flawed economic arguments the industry is prepared to go. ${ }^{132} 133$ Yet these economic arguments are certain to have carried great weight in countries in such economic disarray.

\section{Corporate image}

Finally, BAT's promotion of its corporate image merits comment. We have already seen how the company's image was to be used to promote the company and help market its products, in part to pre-empt the negative impact of potential advertising restrictions. ${ }^{2}$ Here we see the true rationale for BAT's social actions, whether sponsorship of the arts or donations to emergency relief funds: in the short term to promote BAT as a business partner and in the longer term to help sell cigarettes should marketing restrictions reduce access to advertising and increase reliance on corporate image. This highlights again the potential misuse of corporate social responsibility. ${ }^{134}$

\section{Summary}

Overall this paper highlights the considerable priority attached to the former Soviet markets and the disingenuous tactics the TTCs use when negotiating entry to new markets. It highlights the dangers of a rapid transition from socialist to market economies when the supporting institutional structures are not in place and the investing companies use business practices that fall short of international standards. We have previously suggested that empirical studies of the impact of tobacco industry privatisation should be performed before privatisation is recommended, that where privatisation proceeds, health impact assessments should be undertaken and tobacco control measures implemented before tobacco industry privatisation occurs. ${ }^{135}$ Here we suggest that 


\section{What this paper adds}

Previous work has documented the extensive investments made by the tobacco transnationals in the former Soviet Union, yet little if anything is known about the tactics these companies used to establish a manufacturing presence there.

BAT used a variety of arguments to persuade governments to accept its investment. These arguments were largely economic in nature and the absence of any debate on the health impacts of tobacco was notable. BAT exaggerated the potential economic benefits to the country concerned and shaped taxation policies to the benefit of the industry. It emphasised reputed benefits from greater tobacco growing even in countries with little history of tobacco cultivation, thereby gaining the support of the ministries of agriculture. The rapid pace of economic reforms advocated by the global financial institutions meant there were few regulatory structures in place, and helped BAT to avoid competitive tendering. Success often came as a consequence of the notable lack of capacity in the countries concerned to identify and promote their own interests.

governments must be aware of the tactics highlighted in this paper, wary of flawed economic arguments, and better informed of the true economic and health impacts of tobacco in order to make more informed decisions. The international community has a responsibility to help inform governments and assist them in the development of tobacco control capacity and ensure that where privatisation occurs it is properly policed so that benefits to the state are maximised and harms minimised. Experience elsewhere suggests capacity development should occur both within government and civil society, although the latter will be more problematic in countries in this region where the transition to democracy has at best been incomplete. ${ }^{35} 110$

\section{ACKNOWLEDGEMENTS}

This work was supported by the National Cancer Institute, US National Institutes of Health, grant number R01 CA91021. The opinions are those of the authors alone.

\section{Authors' affiliations}

A B Gilmore, M McKee, European Centre on Health of Societies in Transition (ECOHOST), London School of Hygiene and Tropical Medicine, London, UK

\section{REFERENCES}

1 Tomat H. Visit to Moscow from 26th to 30th November 1990. Visit to Kiev from 10th to 11 th December 1990. 20/12/1990. Guildford Depository. BAT. Bates No. 203827452-63.

2 Gilmore AB, McKee M. Moving East: how the transnational tobacco industry gained entry to the emerging markets of the former Soviet Union-part I: establishing cigarette imports. Tobacco Control 2004;13:143-50.

3 Haslam F. Note for TEC. Potential involvement with USSR. 20/02/1989. Guildford Depository. BAT. Bates No. 203827396-411.

4 Brookes N. Note to the CEC. Proposed BAT Tobacco investment strategy in Russia. [1993]. Guildford Depository. BAT. Bates No. 203466243-55.

5 Stiglitz J. Globalization and its discontents. London: Allen Lane, the Penguin Press, 2002.

6 Nellis J. Time to rethink privatization in transition economies. International Finance Corporation, Discussion Paper no. 38, 1999.

7 Havrylyshyn O, McGettigan D. Privatization in Transition Countries: Lessons of the First Decade. Economic Issues no. 18 Washington DC: International Monetary Fund, August 1999. hitp://www.imf.org/external/publc/ft/ issues/issues 18/index.htm [last accessed 15 Jan 2002].

8 The World Bank. Transition the first ten years. Analysis and lessons for Eastern Europe and the Former Soviet Union. Washington DC: The World Bank, 2002.

9 Volodina W, Alexeyev I. Meeting more than the market's demand. Tobacco Journal International 2000;3:27-35.
10 Havrylyshyn O, McGettigan D. A Working Paper of the International Monetary Fund. Privatization in Transition countries: A sampling of the literature (WP/99/6) International Monetary Fund, 1999.

11 Gilmore AB, McKee M. Tobacco and transition: an overview of industry investments, impact and influence in the former Soviet Union. Tobacco Control 2004;13:136-42.

12 British American Tobacco. Eastern Europe/USSR. 2/10/1991. Guildford Depository. BAT. Bates No. 201789795-7.

13 Salter R. New tobacco markets. 13/12/1991. Guildford Depository. BAT. Bates No. 203469386-94.

14 British American Tobacco. New Tobacco markets. 3/6/1992. Guildford Depository. BAT. Bates No. 203469395-403

15 Barton H. NBD Strategy. 18/11/1992. Guildford Depository. BAT. Bates No. 201789654-8.

16 Barton H. New business development strategy. 11/05/1993. Guildford Depository. BAT. Bates No. 203469421-8.

17 Brookes N. Note to Chief Executives Committee: Organisation of new business development. 01/09/1993. Guildford Depository. BAT. Bates No. 203469314-24

18 Barton H. New business development strategy. 17/05/1993. Guildford Depository. BAT. Bates No. 203469331-5.

19 Barton H. Tobacco Strategy Group. 11/12/1992. Guildford Depository. BAT. Bates No. 203469531-3.

20 Barton H. Draft BAT Industries Tobacco Strategy (Tobacco Strategy Group 19th May 1993, Agenda item 7). 12/05/1993. Guildford Depository. BAT Bates No. 203469465-85.

21 British American Tobacco. 1992 Business Review. 1992. Guildford Depository. BAT. Bates no. 203481215-248.

22 Van Waay A. Secret. Note to Mr DS Watterton. Soviet Union. 19/02/1992. Guildford Depository. BAT. Bates No. 203471295-9.

23 Sims D. Memorandum. 17/10/1993. Guildford Depository. BAT. Bates No. 203831282-3.

24 British American Tobacco. Meeting at the premises of BP Exploration Company Ltd., London. 27/05/1992. Guildford Depository. BAT. Bates No. 203461425-6.

25 Rowlands-Rees G. Uzbekistan visit notes - 6th to 17th December 1993. 20/ 12/1993. Guildford Depository. BAT. Bates No. 203835038-41.

26 British American Tobacco. Study on Eastern Europe. 18/01/1990. Guildford Depository. BAT. Bates No. 203825453-92.

27 Barton H. New Business Development-Market prioritisation. 03/12/1992. Guildford Depository. BAT. Bates No. 201789687.

28 J Henry Schroder Wagg \& Co. Ltd. Preliminary review of the Transcaucasian and Central Asian Republics of the former Soviet Union. Volume 1. 28/08/ 1992. Guildford Depository. BAT. Bates No. 203456565-86.

29 Van Waay A. Ukraine-Marketing. 23/04/1992. Guildford Depository. BAT. Bates No. 301689859-61.

30 British American Tobacco. Slide material for DSW presentation 17.2.92: Royal Berkshire Hotel. 17/2/92. Guildford Depository. BAT. Bates No. 203471856-868.

31 Herter U. Note to the board of BAT Industries plc: Central Asian republicsbriefing paper. 27/01/1994. Guildford Depository. BAT. Bates No. 503801076-8.

32 Johnson A. [Letter re Grodno tobacco factory and BAT investment in Belarus]. 01/11/1995. Guildford Depository. BAT. Bates No. 2034769636.

33 British American Tobacco. Protocol of the negotiations between the representatives of the Ministry of Agriculture and Food of Belarus, Belpischeprom, Tobacco Factory Gordno and BAT Industries plc. 12/10/ 1994. Guildford Depository. BAT. Bates No. 203476888.

34 Lioutyi A. Belarus. 30/11/1995. Guildford Depository. BAT. Bates No. 203476960-1.

35 Mihalisko KJ. Belarus: retreat to authoritarianism. In: Dawisha K, Parrott B, eds. Democratic changes and authoritarian reactions in Russia, Ukraine, Belarus and Moldova. Cambridge: Cambridge University Press, 1997.

36 Hewko J. [memo re developments in Belarus]. 14/04/1995. Guildford Depository. BAT. Bates No. 203477007-8.

37 Van Waay A, Bruce-Miller N, Booker M. Secret. Rreport Uzbekistan 18th to 21 st May 1993. 28/05/1993. Guildford Depository. BAT. Bates No. 203832342-65.

38 Lioutyi A. Note for head of Project Uzbekistan Jim Rowland -Rees. 20/12/ 1993. Guildford Depository. BAT. Bates No. 203835035-7.

39 Group Planning Department. BAT Industries - Future Business Environment 1996. Secret. 06/04/1995. Guildford Depository. BAT. Bates No. 500000489-526.

40 British American Tobacco. New Business Development-1992 Strategy Review. [1992]. Guildford Depository. BAT. Bates No. 201789662-8.

41 Marr M, Lewis L. Russia Marketing/distribution study: Yava Factory, Nov. 23-Dec. 6 1992. 25/01/1993. Guildford Depository. BAT. Bates No. 500229032-98.

42 Harington G. Schroders' Visit to Kiev: 13th to 16th October 1992. 21/10/ 1992. Guildford Depository. BAT. Bates No. 203837193-8.

43 British American Tobacco. Draft note to CEC. Valuation of Tobacco Projects In Eastern Europe and the Former Soviet Union. 01/10/1993. Guildford Depository. BAT. Bates No. 202208976-83.

44 Brookes N. Note to Mr U G V Herter. 22/06/1994. Guildford Depository. BAT. Bates No. 600507684-5.

45 British American Tobacco. YAVA-Share acquisition proposal. [10/9/93] Guildford Depository. BAT. Bates No. 203466222-8.

46 Watterton D. Secret. New business development progress report-April 1992. 14/04/1992. Guildford Depository. BAT. Bates No. 20347174856. 
47 Commersant Daily. Philip Morris to buy tobacco factory after all. 20/8/93 Guildford Depository. BAT. Bates No. 203466234-5.

48 Whitehouse A. BAT/Belarus Negotiating Parameters. Guildford Depository BAT. Bates No. 203477144-8.

49 British American Tobacco. Draft 1. Project Umpire Skeleton business plan. [date unknown] Guildford Depository. BAT. Bates No. 301734376-406.

50 Marr M. Moldova marketing plan 1994-2003. Discussion Draft. March 1994. Guildford Depository. BAT. Bates No. 602750435-51.

51 Herter U. Note to Chief Executive's Committee. Uzbekistan. 02/03/1994. Guildford Depository. BAT. Bates No. 503801062-73. checked.

52 Stevens B. Secret. Minutes of the meeting on Eastern Europe 9.00am on 23.1.91, Westminster House, London. 24/01/1991. Guildford Depository. BAT. Bates No. 203827437-41.

53 Whitehouse A. Belarus. 14/06/1995. Guildford Depository. BAT. Bates No. 203476989-95.

54 European Bank of Reconstruction and Development. Moldova: Investment profile. 2001.

55 Weissman R, White A. Needless Harm, International Monetary fund support for tobacco privatisation and for tobacco tax and tariff reduction and the cost to public health. Washington DC: Essential Action, 2002

56 Diaour-Antonenko M. Moldova Agrees to privatise wine and tobacco enterprises. Transitions Online, 16-22 October, 2002

57 Gilmore A, Radu-Loghin C, Zatushevski I, et al. Pushing up smoking incidence: a review of transnational tobacco company plans for a privatised tobacco industry in Moldova. Lancet (in press.)

58 British American Tobacco. Joint venture with tobacco Factory Grodno. 08/ 03/1995. Guildford Depository. BAT. Bates No. 203476804

59 British American Tobacco. Summary of BAT's proposals for the modernisation of Tobacco factory Grodno and benefits to Belarus. 06/03/ 1995. Guildford Depository. BAT. Bates No. 203476805.

60 Zenith Media. Central and Eastern Europe market and mediafact. London: Zenith Optimedia, 2000.

61 ERC Statistics International plc. The world cigarettes I and II: the 2001 survey. Suffolk, Great Britain, 2001.

62 Whitehouse A. Note of a lunch held at BAT with MR Yaroshuk of the Belarusian Ministry of Agriculture on 27th January 1995. 27/01/1995. Guildford Depository. BAT. Bates No. 203477075-6.

63 Hewko J. Memorandum. 20/02/1995. Guildford Depository. BAT. Bates No. 203476839-40

64 Oltermann G. Report on the visit to Grodno on 28/29th March 1995. 31/ 03/1995. Guildford Depository. BAT. Bates No. 203477015-20.

65 Coe L. Note to Anne Johnson Belarus. 20/04/1995. Guildford Depository. BAT. Bates No. 203477004

66 Lioutyi A. Contact with Minister Leonov. 07/07/1995. Guildford Depository. BAT. Bates No. 203476987.

67 Murphy M. Moldova-Initial investment appraisal for leaf processing. 30/ 09/1993. Guildford Depository. BAT. Bates No. 602750677-81.

68 Taylor R. Moldova: Domestic tobacco usage and leaf exports. 04/03/1994. Guildford Depository. BAT. Bates No. 602750570-92.

69 British American Tobacco. [Part of review of Moldovan Tobacco industry]. Guildford Depository. BAT. Bates No. 602750504-14.

70 Taylor R. Subject: visit of Moldovan Minister of Agriculture to Brazil. 21/05/ 1993. Guildford Depository. BAT. Bates No. 602751754.

71 Bruce-Miller N. Uzbekistan-File note-Chairman's visit 14-16/12/93. 17/12/1993. Guildford Depository. BAT. Bates No. 203835033-4.

72 BAT. Press Announcement. BAT Investment in Uzbekistan. 16/05/1994. Guildford Depository. BAT. Bates No. 503801058-9.

73 Sheehy P. [Letter to President Kravchuk]. 07/10/1992. Guildford Depository. BAT. Bates No. 203837060-1.

74 European Bank of Reconstruction and Development, trade exclusion list. http://www.ebrd.com/about/index.htm (last accessed 6 May 2003).

75 Salter R. EBRD. 24/10/91. BAT. Accessed 30 June 2003. Bates No. 201829883. http://www.library.ucsf.edu/tobacco/batco/html/14200/ 14261/otherpages/2.html.

76 Campbell D. BAT Industries plc in the 1980s and 1990s. Stonehouse G Hamill J, Campbell D, Purdie T, eds. Global and transnational business: strategy and management. Chichester: Wiley, 2000.

77 British American Tobacco. Uzbekistan-Cigarette Market. 12/01/1994. Guildford Depository. BAT. Bates No. $203835011-4$

78 Brookes N. Excise issues. 02/12/1992. Guildford Depository. BAT. Bates No. 203475147

79 British American Tobacco. (Secret) Ukraine Business Plan for joint enterprise between BAT Industries Plc and the Cherkassy, Prilucky and Monastirisk Factories. 24/05/1992. Guildford Depository. BAT. Bates No. 301735233-72

80 Van Waay A. Ukraine: Marketing strategy. 05/05/1992. Guildford Depository. BAT. Bates No. 301689856-8.

81 Bruce-Miller N. [letter re visit to Pecs factory]. 10/02/1994. Guildford Depository. BAT. Bates No. 301733123.

82 Herter U. Keynote speech to the World Tobacco Symposium Wednesday 22nd September 1993. Ulrich Herter, Managing Director Tobacco BAT Industries plc. 22/09/1993. Guildford Depository. BAT. Bates No. 203831337-47.

83 British American Tobacco. BAT Industries PLC Reporting Minutes. Secret 19/09/1994. Guildford Depository. BAT. Bates No. 203470846-47.

84 Brookes N. Moldova. 07/06/1994. Guildford Depository. BAT. Bates No. 602750624.

85 Taylor R. Moldova-Leaf purchases by BAT. 07/06/1994. Guildford Depository. BAT. Bates No. 602750622.

86 Brady B. Visit Notes from St Petersburg, Hamburg and Beld (Slovenia). 07/ 02/1994. Guildford Depository. BAT. Bates No. 502649219-20.
87 British American Tobacco. Letter of Intent between Ukrtabakprom and the Prilucky, Cherkassy and Monastirisk factories (hereafter together called "the Ukrainian Partners") and BAT Industries plc (hereinafter called "BAT"). 24/ 02/1992. Guildford Depository. BAT. Bates No. 203836896-900.

88 Johnson A. Meetings in Kiev 23rd \& 24th September 1992. 29/09/1992. Guildford Depository. BAT. Bates No. 203837260-5.

89 British American Tobacco. Memorandum of Understanding between The State Committee of State Property and Privatisation of the Republic of Uzbekistan, the Uzbek State Joint Stock Concern for the Food Industry of the Republic of Uzbekistan (together, the "Uzbekistan Parties") and BAT Industries plc. 29/09/1993. Guildford Depository. BAT. Bates No. 203835130-7.

90 British American Tobacco. Note to the CEC. Uzbekistan. 09/06/1993. Guildford Depository. BAT. Bates No. 203832650-7.

91 Sheehy P. [Letter to President Nazerbayev]. 18/01/1993. Guildford Depository. BAT. Bates No. 203461299-300.

92 Bruce-Miller N. Kazakhstan. 05/02/1993. Guildford Depository. BAT. Bates No. 203461266-9.

93 Van Waay A, Booker RMK. Secret. Report Alma Ata, Kazakhstan 23rd-27th November 1992. 02/12/1992. Guildford Depository. BAT. Bates No. 600001059-67.

94 British American Tobacco. 2001 annual review and summary financial statement. London: BAT, 2002.

95 Brookes N. [Fax from N Brookes re Kazakhstan]. 05/02/1993. Guildford Depository. BAT. Bates No. 203461270

96 TAS (TAS)-Marlboro cigarette production stops in Samara. 21/01/1993. Guildford Depository. BAT. Bates No. 203461271.

97 Unknown. Anon. Taking Stock. Geoffrey C. Bible outlines Philip Morris strategy-past, present and future-for New York analysts. Tobacco Reporter. [01/04/1994]. Guildford Depository. BAT. Bates No. 203459210-2.

98 Taylor R. [Opportunities in CEE and other newly opened markets]. 25/03/ 1993. Guildford Depository. BAT. Bates No. 602750630.

99 Taylor R. [Opportunities in CEE and other newly opened markets]. 25/03/ 1993. Guildford Depository. BAT. Bates No. 602750631.

100 Taylor R. [Opportunities in CEE and other newly opened markets]. 25/03/ 1993. Guildford Depository. BAT. Bates No. 602750632

101 Brookes N. New Business Development Monthly Report to Mid-December 1992. 24/12/1992. Guildford Depository. BAT. Bates No. 20348126773.

102 Van Waay A. Kazakhstan. 16/12/1992. Guildford Depository. BAT. Bates No. 203461354.

103 Van Waay A. Executive Summary. Visit to Alma Ata, Kazakhstan. 03/12/ 1992. Guildford Depository. BAT. Bates No. 203461361-6.

104 British American Tobacco. Proposal for the basis for future co-operation between BAT and AO Donskoy Tabak. 05/07/1993. Guildford Depository. BAT. Bates No. 203466258-63.

105 Wells W. Note of a lunch with Dr Khamidov of UPP at Windsor House of Tuesday 23rd November 1993 at 1245 hrs. 23/11/1993. Guildford Depository. BAT. Bates No. 301728270-3.

106 Watterton D. Secret. New Business Development monthly report-August 1992. 04/09/1992. Guildford Depository. BAT. Bates No. 203471370-5.

107 Gilmore AB. The use of political contacts in establishing tobacco investments in the former Soviet Union, forthcoming.

108 Various. [Details of Philip Morris's proposal for Kazakhstan]. 25/03/1993. Guildford Depository. BAT. Bates No. 203461429-70.

109 Christian Aid. Hooked on Tobacco, Report by Christian Aid/DESER on British American Tobacco subsidiary, Souza Cruz. 2002. http:// www.christian-aid.org.uk/indepth/0201 bat/ [last accessed 3 March 2003].

110 Dawisha K, Parrott B, eds. Conflict, cleavage and change in Central Asia and the Caucasus. Cambridge: Cambridge University Press, 1997.

111 Malone RE. Tobacco industry surveillance of public health groups: the case of STAT and INFACT. Am J Public Health 2002;92:955-60.

112 Philip Morris. List of tobacco control activists. Bates No. 2081380266-73 URL: http://legacy.library.ucsf.edu/cgi/ getdoc?tid $=y \mathrm{kw} 65 \mathrm{c} 00 \& \mathrm{fmt}=$ tif\&ref $=$ results.

113 INFOTAB. Eastern Europe: Lifting the Curtain. October 1990. Guildford Depository. BAT. Bates No. 203825494-509.

114 Wood M. Eastern Europe: a new market ripe for exploitation. [1991] Guildford Depository. BAT. Bates No. 203825529-30.

115 United States Department of Agriculture, Foreign Agricultural Section. Azerbaiian, Republic of: Tobacco and Products Annual Report 2000. GAIN Report \#AJ0002.June 2000. (http://www.fas.usda.gov/gainfiles/ 200003/25637244.pdf)

116 Whitehouse A. Note of meetings held with Salans Herzfeld \& Heilbronn in Warsaw on December 3rd and 4th 1992. 06/12/1992. Guildford Depository. BAT. Bates No. 203842115-8.

117 Burrill DM. Ukraine-Procurator's view. 06/07/1993. Guildford Depository. BAT. Bates No. 301772763-6.

118 British American Tobacco. Living and Working in Moscow City. [01/09/ 1992]. Guildford Depository. BAT. Bates No. 203481072-106.

119 Organisation for Economic Cooperation and Development. OECD guidelines for multinational enterprises: text, commentary and clarifications (October 2001) DAFFE/IME/WPG(2000)15/FINAL, 2001. http:// www.oecd.org/pdf/M00021000/M00021070.pdf [accessed 20 May 2003].

120 Warner KE. The economics of tobacco: myths and realities. Tobacco Control 2000:9:78-89.

121 Lightwood J, Collins D, Lapsley $\mathrm{H}$, et al. Estimating the costs of tobacco use. In: Jha P, Chaplouka F, eds. Tobacco control in developing countries. Oxford: Oxford University Press, 2000. 
122 Jacobs R, Gale HF, Capehart TC, et al. The supply-side effects of tobacco control policies. In: Jha P, Chaplouka F, eds. Tobacco control in developing countries. Oxford: Oxford University Press, 2000.

123 Golden leaf, barren harvest: the costs of tobacco farming, Washington: Campaign for Tobacco Free Kids 2001.

124 Ministry of External Trade and Industry, Kyrgyz Republic. Trade balance for 2000. http://www.mvtp.kg/english/analysis/report2000_1.html [last accessed 21 May 2003].

125 United Nations Food and Agriculture Organisation. FAOSTAT agricultural data. http://apps.fao.org/page/collections?subset = agriculture [last accessed 21 May 2003]

126 Connolly G. Tobacco trade and Eastern Europe. In: Slama K, ed. Tobacco and health. New York: Plenum press, 1995.

127 Mackay J. US Tobacco export to third world: third world war. J Ntl Cancer Inst Monographs 1992;12:25-8.

128 Krasovsky K, Andreeva T, Krisanov D, et al. Economics of tobacco control in Ukraine from the public health perspective. Kiev: Polygraph Center TAT, 2002.
129 Gilmore AB, McKee M. The impact of trade liberalisation on tobacco consumption, the example of the Former Soviet Union. Tobacco Control [submitted].

130 Espindola E. [Details of meetings in Kazakhstan]. [26/11/1992]. Guildford Depository. BAT. Bates No. 203461328-34.

131 International Trade Publications Ltd. World tobacco file 1998-2001. London: DMG Business Media, 1998.

132 Ellison M. Tobacco giant apologises to Czechs. The Guardian, 27 July 2001. http://society.guardian.co.uk/cancer/story/0,8150,528357,00.html [last accessed 3 March 2003]

133 Bates C. Study shows that smoking costs 13 times more than it saves. BMJ 2001;323:1003

134 Collin J, Gilmore A. Corporate (Anti)social (ir)responsibility: transnational tobacco companies and the attempted subversion of global health policy. Global Social Policy 2002;2(3):354-60.

135 Gilmore A. Tobacco and transition: the example of the former Soviet Union. World Conference on Tobacco or Health. Helsinki, 2003.

\section{The lighter side}

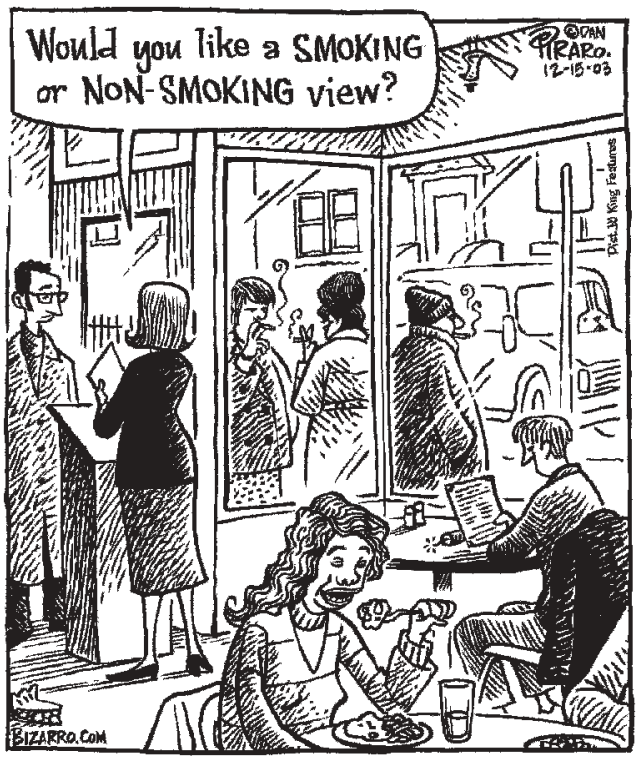

(c) King Features Syndicate. Reprinted with permission of Torstar Syndication Services. 